Article

\title{
Agents of Change in the Domestic Built Environment
}

\author{
Fani Kostourou \\ Bartlett School of Architecture, University College London, UK; f.kostourou@ucl.ac.uk
}

Submitted: 28 April 2021 | Accepted: 2 August 2021 | Published: 11 January 2022

\begin{abstract}
As our cities age, a large number of spatial structures experience physical change. A better understanding of what this process may entail and the agents involved in it can extend the knowledge of practitioners, activists, and policy experts regarding the resilience of our domestic building stock and cities. Awan et al. (2013) explain that agents are not entirely free from societal and spatial constraints; instead, they are characterised by intent, shaped by their own visions and actions, and context, the spatial and social structures of which they are part and which they negotiate. This article discusses the intent and context of the agents involved in the construction and transformation of the Cité Ouvrière in Mulhouse in Eastern France from the mid-19th century to date. With 1,253 houses built for the workers of the Dollfus-Mieg et Compagnie (DMC) textile factory between 1853 and 1897, Cité Ouvrière was the largest and most successful employer-constructed housing scheme of its time, setting an example for many other European company towns. Through this exceptional case study, the article identifies the levels at which spatial agents operate, the means they use to instigate change, their dynamic relations, and the ways these are influenced by the wider historical context while influencing the making and evolution of the built form. Using historical and archival documents, it amounts to recognise an interplay of individuals and public and private groups, who have been responsible for taking decisions at different scales - the city, the neighbourhood, and the houses-and have instigated changes of different effect-from more localised to more aggregate.
\end{abstract}

\section{Keywords}

actor-network; built environment; Cité Ouvrière; historical longitudinal study; Mulhouse; spatial agency; urban change

\section{Issue}

This article is part of the issue "City as Flux: Interrogating the Changing Nature of Urban Change" edited by Aseem Inam (Cardiff University).

(C) 2022 by the author(s); licensee Cogitatio (Lisbon, Portugal). This article is licensed under a Creative Commons Attribution 4.0 International License (CC BY).

\section{Introduction}

As our built environment ages, the forms and infrastructures of our cities undergo a constant process of physical change (demolitions, adaptations, extensions, typological mutations, etc.) due to various functional, political, socio-economic, cultural, ideological, and technological developments. Although in my work I have already explored some of the spatial manifestations of such processes, looking, for example, at the densification of houses (Kostourou, 2021) or the formal adaptability of streets, buildings, and plots (Kostourou, 2020), it is worth focusing here on the human-individual and collective-agents involved in these processes of change. Foregrounding the means of change instrumentalised by these agents and the dynamic and evolving relationships between them over time can significantly expand the current understanding of architects, planners, activists, and policy experts with regards to the impact of their decisions on the resilience of our building stock and cities in the longer term.

"Agency" is defined here as the ability of individuals and social entities "to intervene in the world, or to refrain from such intervention, with the effect of influencing a specific process or state of affairs" (Giddens, 1984, p. 14). In their book, Nishat Awan, Tatjana Schneider, and Jeremy Till (Awan et al., 2013) adopt sociologist Anthony Giddens' take on agency, further explaining that spatial agents are not entirely free from societal and spatial constraints, but they have the power to negotiate these while engaging with their spatial environment. The authors identify two main features in agents: (1) the 
intent shaped by their own visions and actions; and (2) the context, meaning the spatial and social structures of which the agents are part of and which they negotiate.

In this article, I wish to discuss the intent and context of the spatial agents involved in the construction and transformation of the 19th-century Cité Ouvrière in Mulhouse, in Eastern France (Figure 1). With 1,253 houses built for the workers of the Dollfus-Mieg et Compagnie (DMC) textile factory between 1853 and 1897, Cité Ouvrière was the largest and most successful employer-constructed housing scheme of its time. As I will show, it set an example for many other European company towns, on account of its social innovations, a new housing typology, and a financial model that provided workers with subsidised access to property.

The article will discuss which agents have been associated and engaged with the specific housing scheme and how they have affected its formation and transformation to the present. Relying on historical and archival documents, the research seeks to highlight combinations of different public and private groups and individuals that have influenced social and spatial structures at different scales, from the level of the city and the neighbourhood to the level of individual buildings and plots.

\section{Spatial Agency}

While Awan et al. (2013) have created an extensive repository of examples of spatial agency, grouping "the motivations (why?), locations (where?) and means (how?) of Spatial Agency... [and] opening up to an international network of spatial agents" (Schneider \& Till, n.d.), they have not explored the dynamic and complex relationships between different spatial agents in one location through time. In social theory, Bruno Latour (2005) has famously developed the concept of "actor-network theory" as a way to describe the ever-shifting connections and interactions between different social, techni- cal, or scientific structures; in other words, networks of relations between objects-human and non-humanas well as between ideas and processes. One of the most accessible application of that approach in architectural theory can be found in the work of Albena Yaneva (2012), who has traced well-known debates around contested sites like the Olympic Stadium in London or the Welsh Parliament in Cardiff, challenging any static understanding of such ecosystems beyond what is visible to the naked eye. Before that, urban morphologist Jeremy Whitehand (1992) had discussed spatial agents involved in the development of urban landscapes. Taking as an example the city of Birmingham, he had detected the agents of local government, individuals and families, religious bodies, societies, and private enterprises (Figure 2 ). He found that in institutional and public areas the dominant agents were the local municipality and business elite, and in residential areas there were the landowners (individuals and the municipality), developers (architects, craftsmen, merchants, traders, etc.), and builders. During certain periods in the history of the city, such as the inter-war period (1919-1938), decision-making on all three elements of urban form (streets, buildings, and plots) were in the same hands: the owners and the developer-builders. Ultimately, Whitehand distinguished spatial agents based on the role they perform, i.e., owners, architects, builders; the degree of concentration in decision-making, associating, for instance, the concentration of authority with uniformity in the design; and, lastly, the type of activities, particularly between corporate or public and individual or private. The latter distinction had already been identified by Michael R. G. Conzen (1988) who argued that corporate initiatives formed the layout of medieval towns which individual initiatives transformed later until the late 19th century.

Embedded within the idea of agency are the drivers of change-or else, intent-which include larger forces such as changes in the economy, politics, or

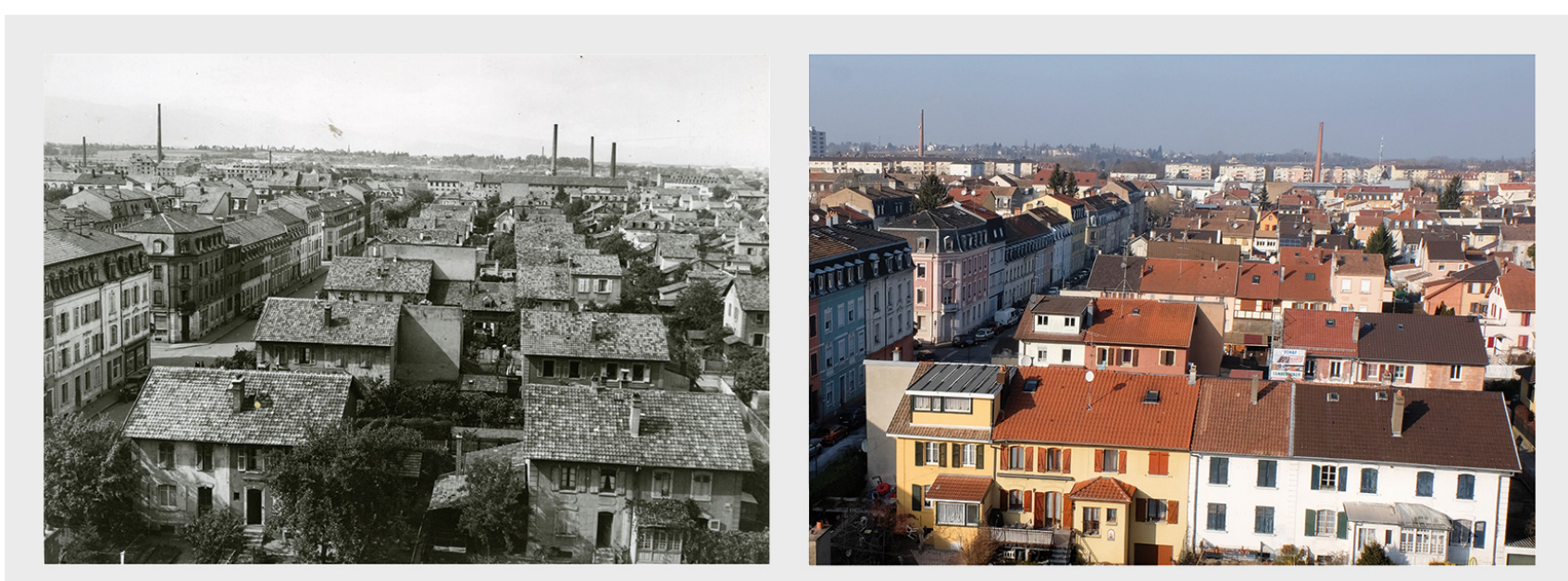

Figure 1. View of the western part of Cité Ouvrière (Rue des Oiseaux) from the bell tower of Saint-Joseph church in 1901 (left) and 2017 (right), photographed using the same vantage point. Source: Archives de Mulhouse collection (left) and Luc Georges (right); edited by the author. 

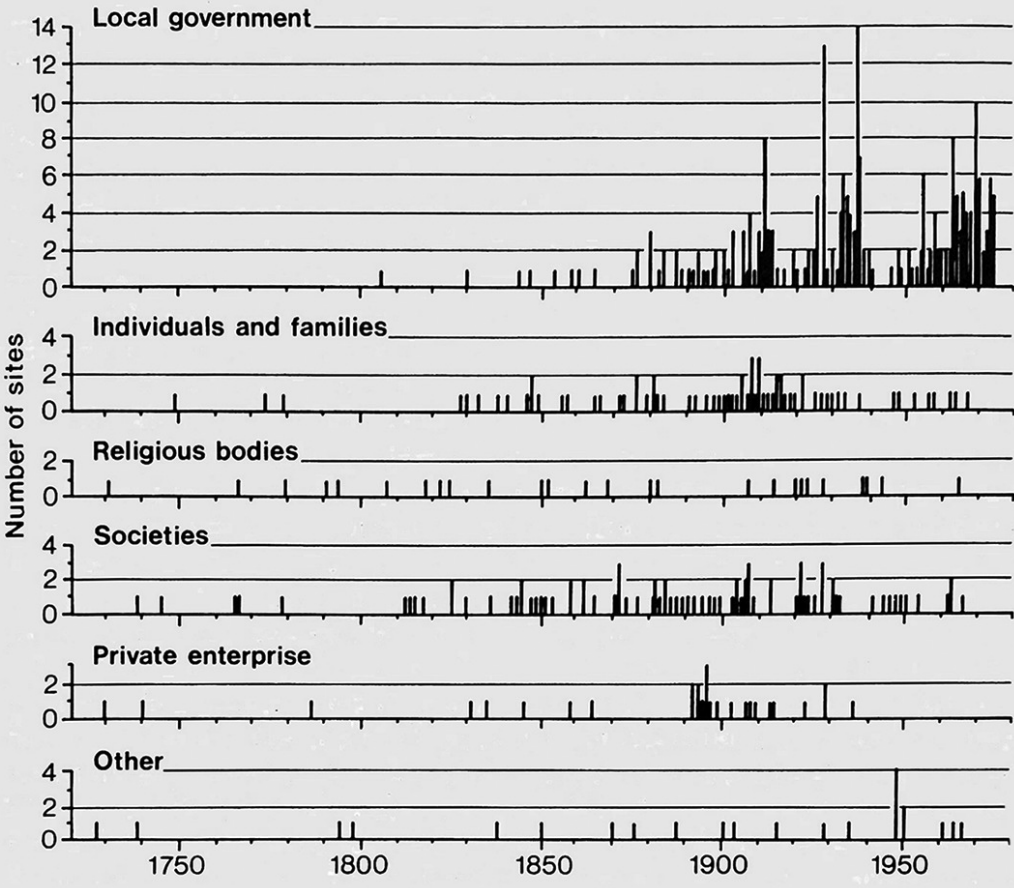

Figure 2. Agents developing institutional and public areas in Birmingham from 1730 to 1973. Source: Whitehand (1992, p. 94).

technology (Brand, 1994; Steadman, 2014; Whitehand, 1992). Equally, social factors like birth rates, migration, shared ideas, lifestyles, and habits have the power to construct spatial cultures that produce distinctive spatial milieus (Hillier, 1989; Kropf, 2001). The relationship between socio-economic and physical changes is explained well by Spiro Kostof (1992, p. 292): “Urban process represents the adjustment of the urban fabric to a whole variety of changes that are economic and social. These changes are often swifter and more deep-seated than the pace and range of physical change."

Literature draws our attention to the means (how) and reasons (why) spatial agents may instigate changes in the built environment, the wider context in which they operate, and the dynamic relationship between the two as well as the agents themselves. What follows is a longitudinal exploration of these questions using the Cité Ouvrière in Mulhouse as a case study. The article looks at the conditions associated with the initial development of the housing scheme in the city and its subsequent transformation over a substantial period of time, i.e., more than 160 years. The article does not only discuss the agents responsible for changes in the scheme at different stages but also situates them within the wider historical context they have been operating all this time, while also referring to circumstantial socio-political ideologies and technical innovations. Although the study is contextual, more generalised lessons which are useful for urban planners, policy makers, private developers, individual citizens, and activists working and living in the built environment can be extracted in the end.

\section{Context}

In France, cités ouvrières (working-class settlements) were introduced by Napoleon III after he came to power in 1848. It was just at that time that the movement of Social Catholicism, which had been strongly supporting the housing reform since the beginning of the century, gained significant ground. Napoleon sponsored low-income housing to pacify the masses and to win a favourable reputation for the imperial regime. Meanwhile, the bourgeois industrialists embarked on grand worker-improvement schemes to portray their paternalistic benevolence as welfare assistance (Clement, 2018; de Gier, 2014; Kostourou, 2019). Although the various decision-makers shared a common objective - to rebuild society and especially its workingclass section through the provision of housing-they differed on their approach to achieve that (Shapiro, 1985). Specifically, Napoleon III and Haussmann advocated for programmes of public works, the hygiene professionals demanded tighter health laws, and the socialists lobbied to secure state intervention and limit private speculation.

\subsection{The Mulhousian Model}

Outside Paris, Mulhouse was one of the few French cities featuring a conjunction of favourable conditions that allowed it to respond promptly to the housing question of the time. Situated in the Alsatian region of Eastern France, close to Switzerland and Germany, the city always had a special relationship with its neighbouring 
countries. It was one of the 10 free imperial cities of the Holy Roman Empire; then, it became an autonomous Calvinist republic in 1347, allied to Swiss cantons from 1515 until its reunion with France in 1798 under a rather favourable treaty. This long tradition of the city as a selfruling entity as well as its strategic position between three "powers" helped the city to grow richer during the Thirty Years' War between the Protestant and Catholic states (1618-1648), and to invest its accumulated capital into industry. Effectively, it featured both a political and an economic "extraterritoriality" (legal ability to exercise authority beyond the normal boundaries) mainly because of the Protestant, liberal, and entrepreneurial spirit of its local bourgeoisie (Jonas, 1994). In the words of a local literature teacher, Emile Boissière (1876, p. 48, translation by the author), "Mulhouse was a city of men's initiative, who handled municipal affairs alone without asking for anything from the government other than the time to do so."

This political independence and Reformist theological tradition nourished the city's industrialisation (Stoerkel \& Vitoux, 2018). While the Industrial Revolution was timid in the rest of the country, Mulhouse experienced radical and rapid economic growth at the end of 18th and beginning of 19th centuries based largely on textile industries. With 55 factories within and outside its walls in 1830 , the city soon became known as "the industrial capital of Alsace," the "city of hundred chimneys" inspired by Engelmann's lithograph (Figure 3), or the "French Manchester" due to the example set by the British city (Scheurer \& Lehni, 1990). Indeed, Mulhousian factories pioneered the textile printing industry (impression sur étoffes), especially artistic calico printing, and the development of mechanical cotton spinning and weaving (Schmitt \& Jenkins, 1982).

The industrialisation process was launched, designed, and run entirely by a small group of Protestants, Freemasons, paternalistic bourgeois manufacturers yet philanthropists, who dominated the municipal cabinet and favoured the reformist agenda. Historian William Clement (2018) explains how the same elite families, such as Dollfus and Koechlin, had ruled the cityrepublic, founded the first factories, and monopolised political posts (until 1871, all mayors were Protestant industrialists), perpetuating a strong "fabricantocracy" for centuries. Their role was twofold: As individuals, they were interested in the accumulation of capital and the expansion of their private businesses; meanwhile, they sought to form associations and engage in philanthropic activities to retain the power of the bourgeoisie. In 1826, they founded the Société Industrielle de Mulhouse (Mulhouse Industrial Society [SIM]) to

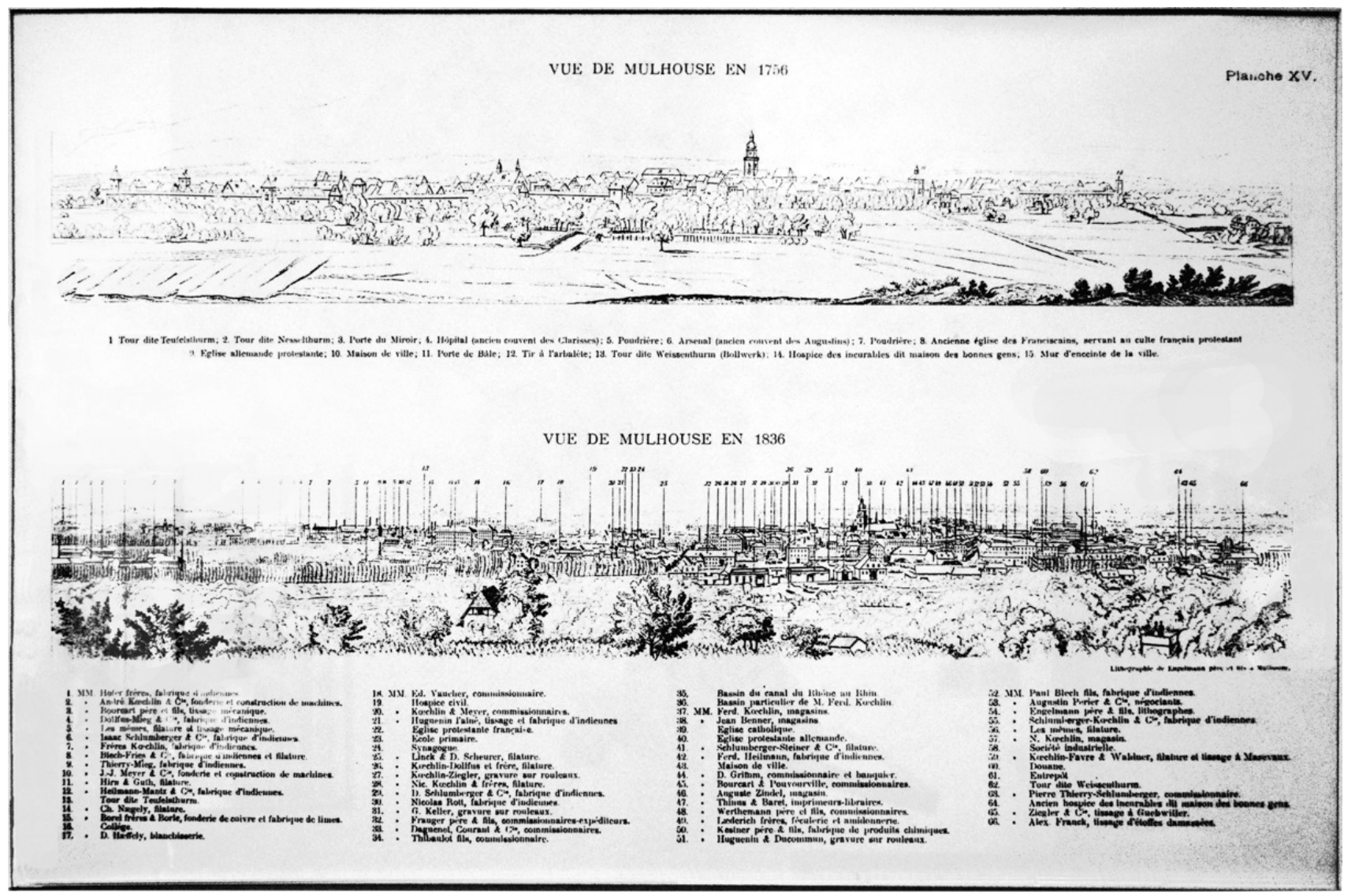

Figure 3. View of Mulhouse in 1756 and 1836. Lithograph by Godefroy Engelmann indicating the geographical location of all the factories and the civic buildings in Mulhouse and its peri-urban territory. The image illustrates the radical growth of the city during the First Industrial Revolution. Source: Musée de l'Impression sur Étoffes collection. 
advance manufacturing and agricultural industries, to promote scientific research and vocational training, and to instil in the working class basic liberal values such as love for work, frugality, and education (Jonas, 1994). Twenty-seven years later, they established the Société Mulhousienne des Cités Ouvrières (Mulhouse Society for Working-Class Housing [SOMCO]) to meet the demographic pressure as a result of the industrial boom. They also undertook charity work for poor and malnourished workers by setting up welfare childcare facilities, savings banks, a public school-even before the adoption of the Guizot law on compulsory primary education-as well as the first National Institution of Higher Learning in Chemistry in France.

In that sense, their philanthropy exceeded paternalism for they aimed to improve workers' lives, emancipating them from their supervision and control. This resulted in a Mulhousian model that was very distinct and ahead of its time in combining public and private initiatives. It relied on three pillars: the entrepreneurial spirit of Protestant employers, the involvement of municipal organisations, and the contribution of the workingclass, all in the search for a better social balance (Figure 4).

\subsection{The Cité Ouvrière Model}

Under these circumstances, Cité Ouvrière was built between 1853 and 1897 for the workers of the DMC textile factory. The project was funded by SOMCO on the initiative of Jean Dollfus-head of DMC and mayor of Mulhouse between 1863 and 1869-with contributions from the municipality and the state (only for the first phase of the development). The philanthropic endeavour was a response to the poor living conditions of the working class, surveyed and reported by Dr. Louis René Villermé in 1840, Dr. Achille Penot in 1843, and Louis
Reybaud in 1858 (Jonas, 2003). The objective was to offer workers salutary, comfortable, and affordable housing and the opportunity to access homeownership after a period of 13 to 15 years. The three-phased construction lasted 44 years, producing a homogeneous array of 1,253 low-rise, single-family dwellings (back-to-back, terraced, semi-detached, and quarter-detached typologies) with gardens and a few collective facilities.

\subsubsection{The Realisation of a Utopia and Inventive Pragmatism}

Cité Ouvrière started as a projet idéal (Jonas, 2003, p. 116), a utopian project conceived by the architect Emile Müller with consultations from SOMCO and SIM to shape the moral and spiritual qualities of the working class through its architectural and urban design. For example, by providing gardens on each plot, Müller sought to serve the reformist idea that a "jardin ouvrier minimum" (small garden for workers; Véron, 1866, p. 16) would keep the men away from the cabarets and the entire household would spend time on growing vegetables to provide daily food and improve their income (Simon, 1861). From a formal perspective, the design of projet idéal was based on three key ideas: First, a central square would constitute the spatial and social centre of the settlement; second, a relatively high number of streets in combination with single-family typologies with direct access to them would help reducing overcrowding by keeping families separate, serving the hygienic ideas of housing reform; and third, uniformity in the urban and architectural plan would reflect the concentration of authority by the industrialists and mirror the streamlined layout of the factory. From a socio-economic perspective, the project sought to provide innovative-for the time-amenities such as public baths, a communal house with rooms

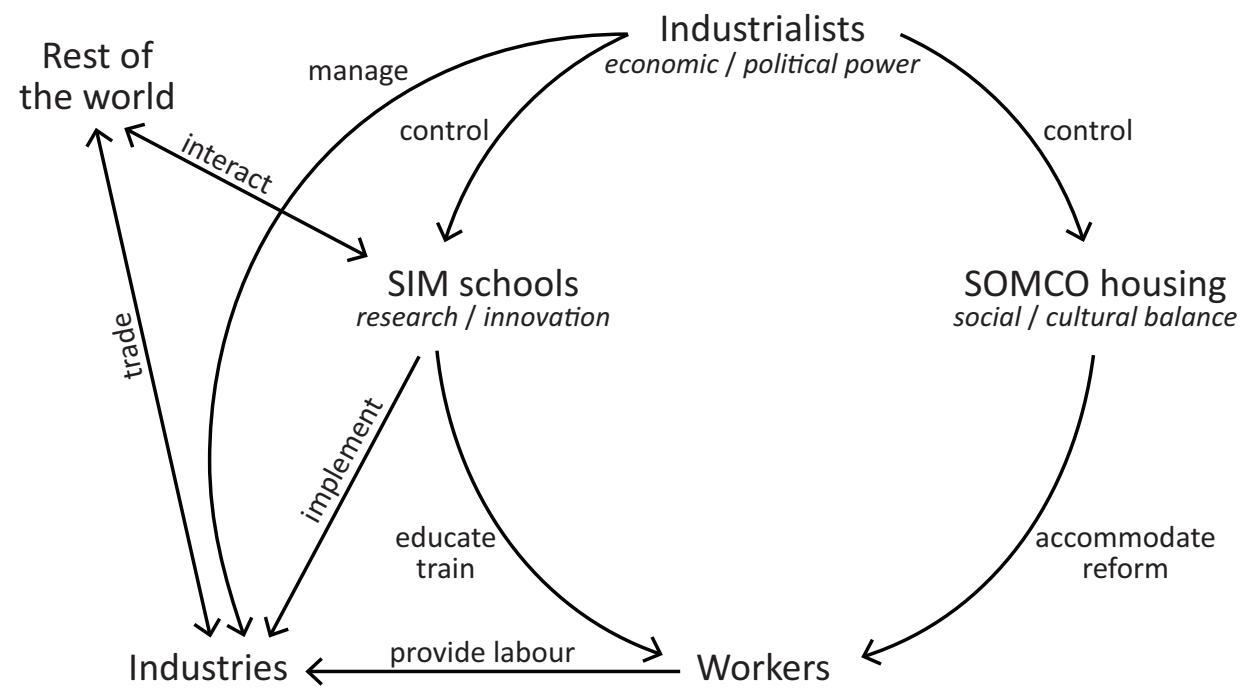

Figure 4. Diagram of the Mulhousian social model, featuring the agents and their relations. Source: Author's work, based on M. Fou's diagram (https://commons.wikimedia.org/wiki/File:Modele_mulhousien.png). 
for meeting, reading, and learning, laundry, butchery, and the Société de Consommation des Cités Ouvrières (Society of Consumers in Working-Class Housing), a cooperatively-led business which traded locally baked goods, groceries, clothes, etc., to initiate the workers into the domestic habits of the bourgeoisie (Garner, 1992). It was believed that these benefits would enhance the production routine and shape the social and cultural capital of the local working class (Jonas, 2003; Penot, 1867).

Eventually, the projet idéal was not realised to its full extent, due to limitations on available funds-especially from the state-and the low demand of workers for houses at the time of the construction. Although some of the original ideals were compromised in the pursuit of financial practicality, this does not imply that the first cité (Figure 5) failed to constitute a pioneering workers' housing scheme. In fact, most of the public amenities and formal ideas were realised, making this a testbed for financially partnering the public and private sector, developing a financial model to access property, applying advanced hygienic measures, testing new domestic built forms, and promoting an innovative social model and welfare work policy. Besides the communal facilities, the first cité also offered a pension scheme, mutual aid provisions, free medical services, and a vocational training school (de Gier, 2014).

Interestingly, the two subsequent phases were less ambitious than the first one, both as urban, social, and economic models. Soon after the project began, SOMCO struggled to sell or rent houses from the first cité because of the economic crisis of 1853-1856. Furthermore, after the Franco-Prussian War of 1870, Mulhouse was annexed to the German Empire, which saw the abandonment of the previous welfare work policies. Public funding was no longer available and SOMCO had to pay fully for the public infrastructure, such as the provision of public squares, the expansion and transformation of the public baths and laundries, the installation of sewage system, and the construction of new streets (Jonas, 2003). Meanwhile, the project attracted other private developers in the area who started to offer workers alternative low-cost accommodations in nearby locations. These goaded SOMCO into making adjustments in the operational model; for example, they allowed the subleasing of part of the houses and adapted the housing prices according to the changing wages of the workers. As the sociologist Stéphane Jonas (2003, p. 115) argues, these decisions showed the "inventive pragmatism" of SOMCO and Dollfus, meaning an empiricism of common sense that led them to adjust the project in response to political changes, the city's industrialisation and growth, and the lessons learned from the outcomes of the first experiment.

Spatially, these decisions had little bearing on the street form, but a greater impact on the built form. In view of the financial struggles and market competition, the association and the architect decided to shrink and standardise the houses and reduce their typological variety and floor area (Figure 6). Gradually, the image of the Cité became more monotonous. During the third and last development phase, the built form changed again. The successor to Jean Dollfus as the head of SOMCO, Alfred Dollfus, decided to provide, unlike his predecessor, taller and larger houses for affluent workers who could sublet parts of them to unskilled workers to generate income. Interestingly, Jonas (2003) claims that SOMCO halted the construction of smaller and cheaper houses, susceptible to extensive adaptations by the inhabitants

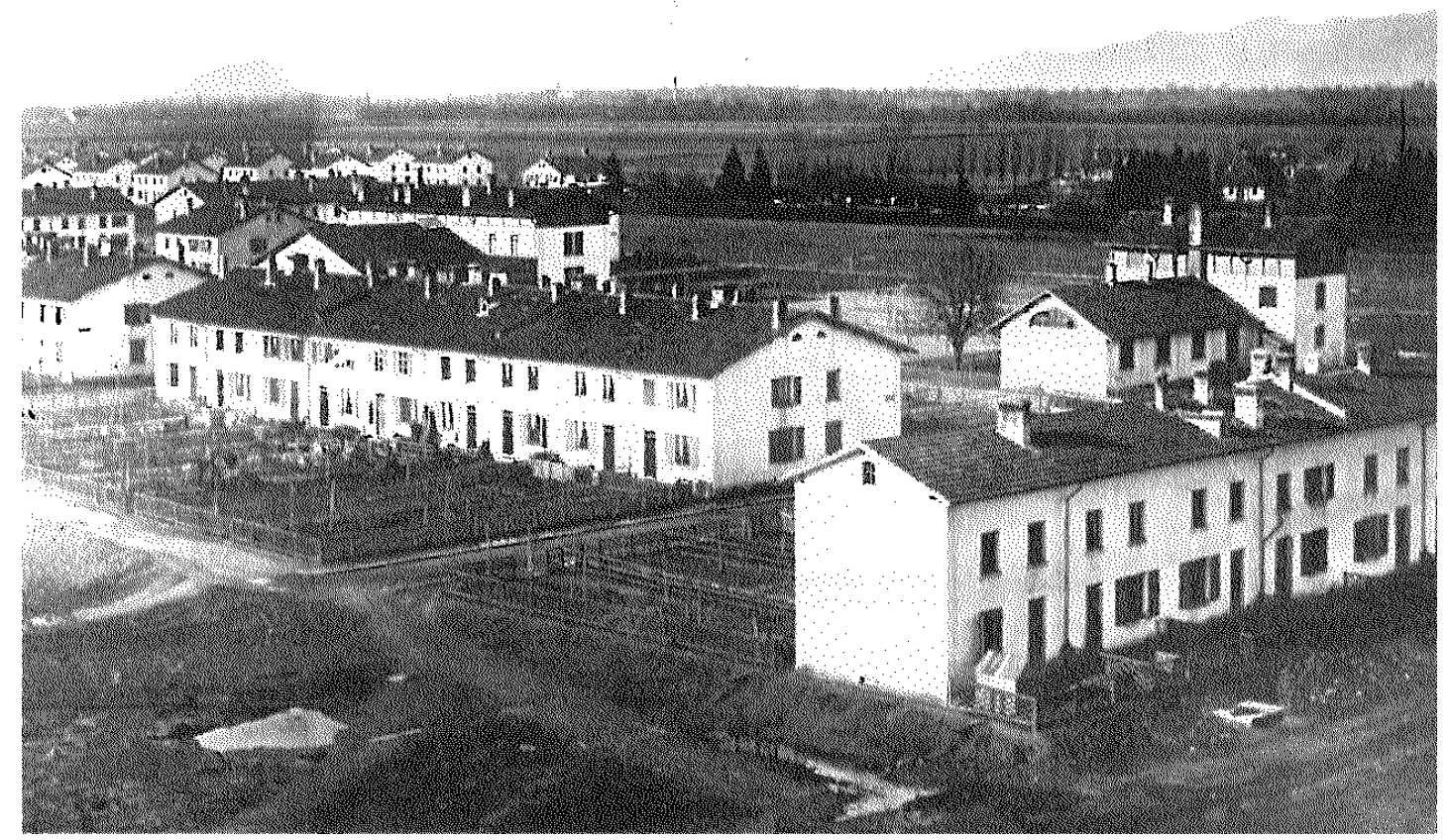

Figure 5. View of the first development phase of Cité Ouvrière in Mulhouse, ca. 1857. Source: Jonas (2003, p. 136). 


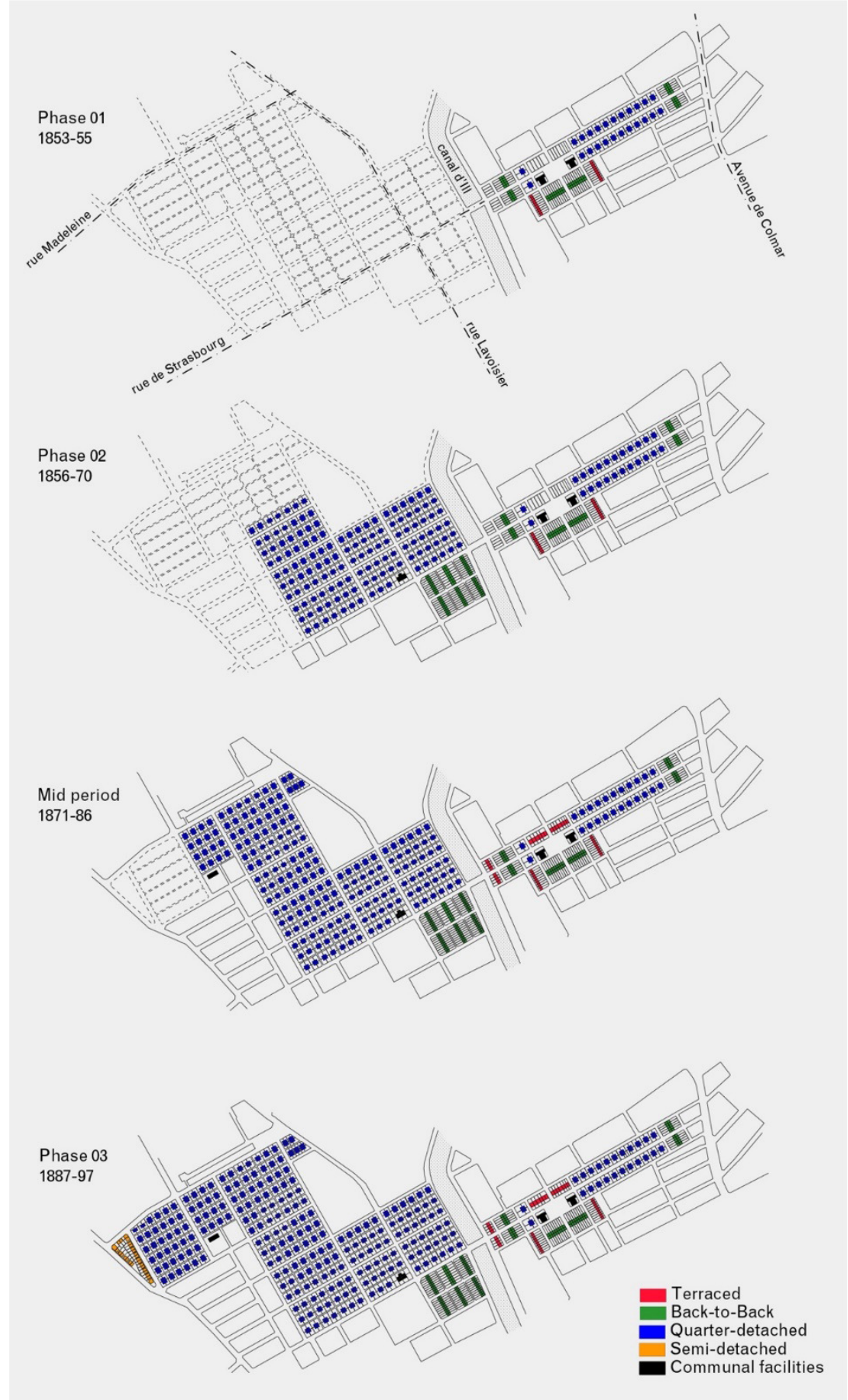

Figure 6. Construction phases of Cité Ouvrière and standardisation of housing typologies. Source: Kostourou (2020, p. 107).

because the industrialists considered such changes an "aesthetic of the poor" and "disgraceful" (de Lacroix, 1901, p. 447), for it ruptured the uniformity of the Cité and spoiled the homogeneous image that a mass lowcost housing scheme should have had at the time.

Even during the 44 years it took to complete Cité Ouvrière, both its form and infrastructure, as well as the social model and economic policy it provided, were constantly revised and adjusted by SOMCO and the architect based on the experience and evidence they were gathering from the previous phases.

\subsubsection{A Cité Par Excellence}

Besides the unique Mulhousian model that made such an endeavour possible, the Cité Ouvrière was influenced by previous developments in London, Brussels, and Paris. The first city offered inspiration on the formation of housing associations, architectural typologies, especially those published by the British architect Henry Roberts in 1850, and planning laws. Brussels showed the importance of hygiene reports and of municipal participation on residential projects, such as the Cité de 
Grand-Hornu in Boussu (1810-1830) and the Cité of Grandes Rames in Verviers (1808-1810), known thanks to Edouard Ducpétiaux (1846). Paris showed the influence of Social Catholicism and the governmental policies on housing that had already started with the establishment of the first Société des Cités Ouvrières de Paris and the erection of the first working-class scheme in the country, the Cité Napoléon (1849-1851; Jonas, 2003).

Nonetheless, the Mulhousian Cité became internationally renowned as the largest and most successful realised example of employer-constructed housing in Europe for the years 1850-1870 (Jonas, 2003). At the 1856 Exposition d'Économie Domestique in Brussels, the scheme was seen as the epitome of working-class housing, while in the 1867 Exposition Universelle (d'Art et $d^{\prime}$ Industrie) in Paris (Figure 7) it won the golden medal for presenting a full-scale model of a cluster of four quadruplex houses, a typology known in French as the carré mulhousien (Clement, 2018; Jonas, 2003).
The project became known in Britain through the architect Henry Roberts. Both Müller and Dollfus shared the scheme's details with Roberts at the Congrès International de Bienfaisance in Brussels, in 1856, and in London, in 1862 . This was enough to convince Roberts of its innovative nature in terms of social and financial organisation. Roberts $(1867$, p. 57$)$ notes that the Mulhousian Cité was done "on a scale more extensive and complete than that of any similar establishment in France." The British Daily News of 1866 also recognised it as equivalent to the UK textile workers' town of Saltaire, near Bradford (Clement, 2018), while a year later the British magazine Engineering praised its effectiveness in "decreasing labour disputes and increasing industrial productivity" (Ermenc, 1957, p. 130), referring to the friendly relationships between the employers and the employees.

Inevitably, there were many attempts to copy the example in other French cities, though, as Clement (2018,

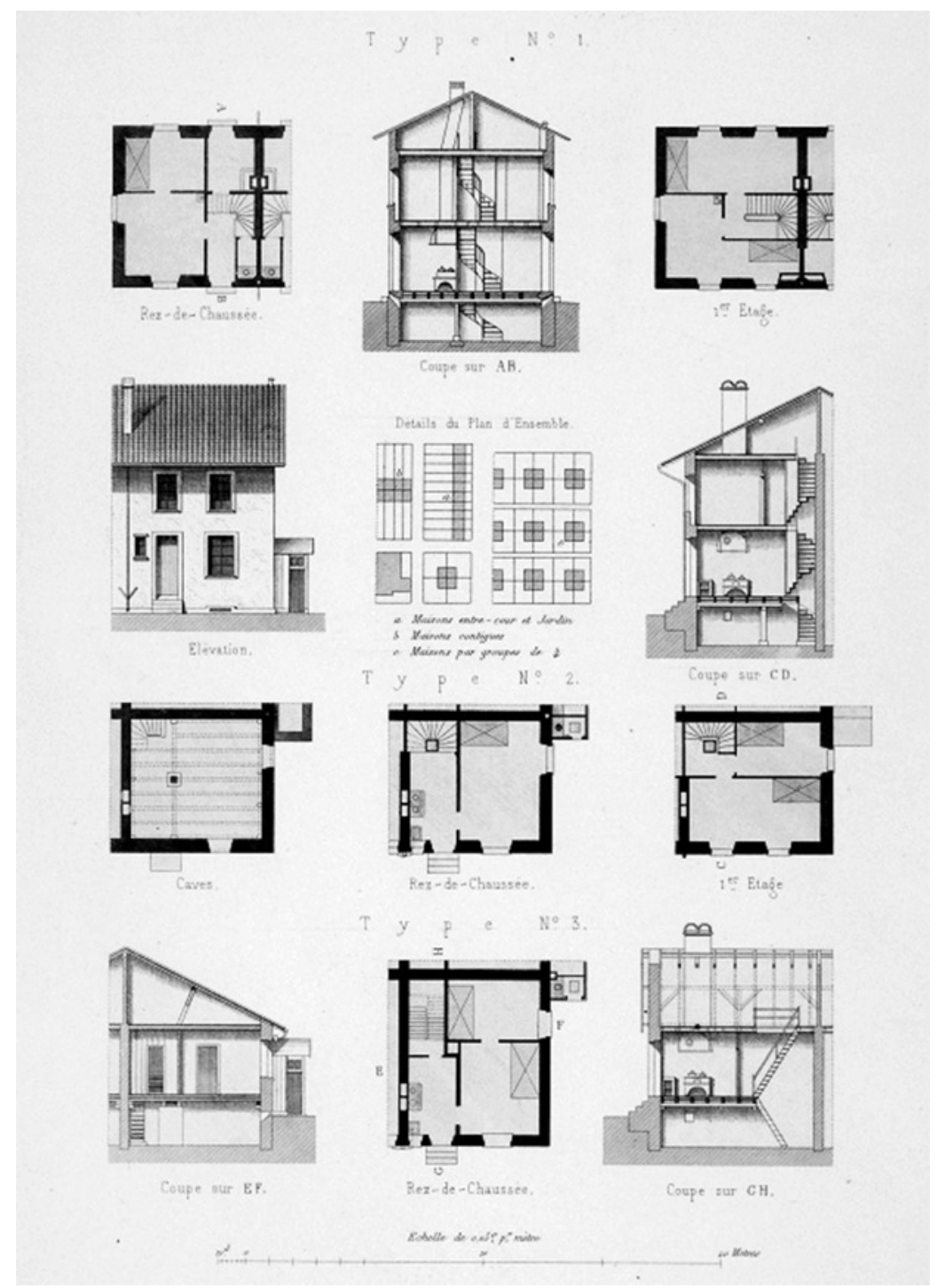

Figure 7. Housing typologies presented to the visitors of the Exposition Universelle in Paris, 1867, and published in Revue générale de l'architecture et des travaux publics. Source: Canopé Académie de Strasbourg (n.d.). 
p. 18) argues, these efforts had limited success without the "shared desire of the overlapping municipal and industrial elites to improve housing" and the favourable conditions of the Mulhousian model. In France, cities like Lille, Roubaix, Bordeaux, and Nancy contacted the local authorities for plans; however, either the projects were small-scale, or the social policies were rather paternalistic. For example, architectural historian John S. Garner (1992) notices that while the Cité Scrive de Marcq-enBaroeul in Lille (1854) was meant to replicate the Cité Ouvrière model, the society was more closed and subordinate to the company than in Mulhouse, and, instead, mechanical discipline and social order were imposed. Within the Alsatian region, the attempts proved to be more successful because there were similar political and religious conditions as well as ties to Mulhousian associations. Realised examples include Herzog in Colmar (1866), the Cité Bourcart in Guebwiller (1856), and the Japy's Village at Beaucourt (1864; see Boissière, 1876; Guerrand, 1967).

The Cité Ouvrière also influenced developments outside France, such as the settlements built by BASF, Farbwerke Höchst, the Bochumer Verein, and other Ruhr mining and chemical companies in Germany (Honhart, 1990). It also inspired entire neighbourhoods like the Cité de Linthout in Schaerbeek, Brussels (Smets, 1977; Viaene, 1994). Furthermore, the typology of quarterdetached houses was copied in workers' settlements in Küchen (Belgium), in Krähnholm (Russia), and in Bubna, Buda, and Pest (Austro-Hungarian Empire), while the idea of providing gardens for cultivation by the household inspired the hotel Louise (1872) in Micheroux, Belgium (Müller \& Cacheux, 1889a).

\section{Agents of Change}

Both during the development of the settlement but also right after its completion, individual houses and plots began receiving a large number of small-scale extensions and modifications that emerged gradually from the bottom-up, i.e., as a result of many individual human actions (Figure 8). The inhabitants and owners incrementally expanded their houses, altered the roofs and facades, added sheds, garages, shops, and workshops, or rented out parts of their holdings for income (for more on physical changes and housing growth see Kostourou, 2021). In that sense, the delivery of the project ushered in a new "development" period of major extensions and modifications that was not planned by SOMCO or the municipality.

In the chronicle of this project's conception, phasal development, and post-occupational growth, a combination of different kinds of agents using different means to instigate changes at different scales is identified: At city level, the principal agents are public, namely the local authorities and the state; at the level of the neighbourhood, agents are both public and private, ranging from the state, the municipality, SOMCO, especially Jean
Dollfus, and the architect Emile Müller, as well as the workers-inhabitants; and at the level of buildings and plots, the main agents are the inhabitants, the architect, and the local authorities. The agency of these actors has been primarily effected through their visions, decisions, and actions and spatially expressed in changes in the built environment. Table 1 summarises all these observations.

\subsection{The State}

The state represented by its emperor Napoleon III in the mid-19th century supported a programme of public housing in France. With sociologist and economist Frederic Le Play as counsellor of state, housing initiatives were directed towards the reformist agenda informed by Le Play's study on the socio-economic condition of the European working classes. This culminated in subsidising private enterprises. Cité Ouvrière was the first scheme outside Paris financially supported by the government. Following the French housing act of 1852, the government contributed $F 150,000$-equivalent to approximately $€ 460,000$ today (Monange, 2001)-and the municipality added another $F 150,000$ to cover the public infrastructure of the first cité (Jonas, 2003). Furthermore, the entire model was based on the "philanthropy of $4 \%$ "-instead of five, which was the case in Britain (Tarn, 1973)-meaning that SOMCO collected only $4 \%$ return on its original investment (Jonas, 2003). Meanwhile, the land on which Cité Ouvrière was built was cheap, $1 \mathrm{~F} / \mathrm{m}^{2}$-in comparison to $75 \mathrm{~F} / \mathrm{m}^{2}$ for the Cité Napoleon in Paris (Bullock \& Read, 1985)-because the land was originally owned by Jean Dollfus who granted it to SOMCO at a low price. This helped to keep the average cost of houses low, ranging between $F 1,850$ and $F 3,500$, depending on the building type (Müller \& Cacheux, 1889b). Although eventually state funding was delayed, the promised amount $(F 300,000)$ was not deposited in full and it did not continue in the subsequent development phases, this marked an important political decision that established a welfare approach to working-class housing. The involvement of the state here is one of the earliest examples of publicprivate partnerships (PPP) in housing and urban development, arriving more than a century before PPP became popular in project finance. Unfortunately, in the subsequent development phases the socio-economic model started to become brittle, revealing the limitations of liberal philanthropy.

\subsection{The Municipality and the Housing Association}

The municipality in collaboration with SOMCO were instrumental in the development and subsequent evolution of the scheme by supporting the industrial production, undertaking charity work for the poor and disadvantaged employees, setting up welfare and public facilities, and offering the workers salutary and affordable housing with the possibility to access homeownership. 


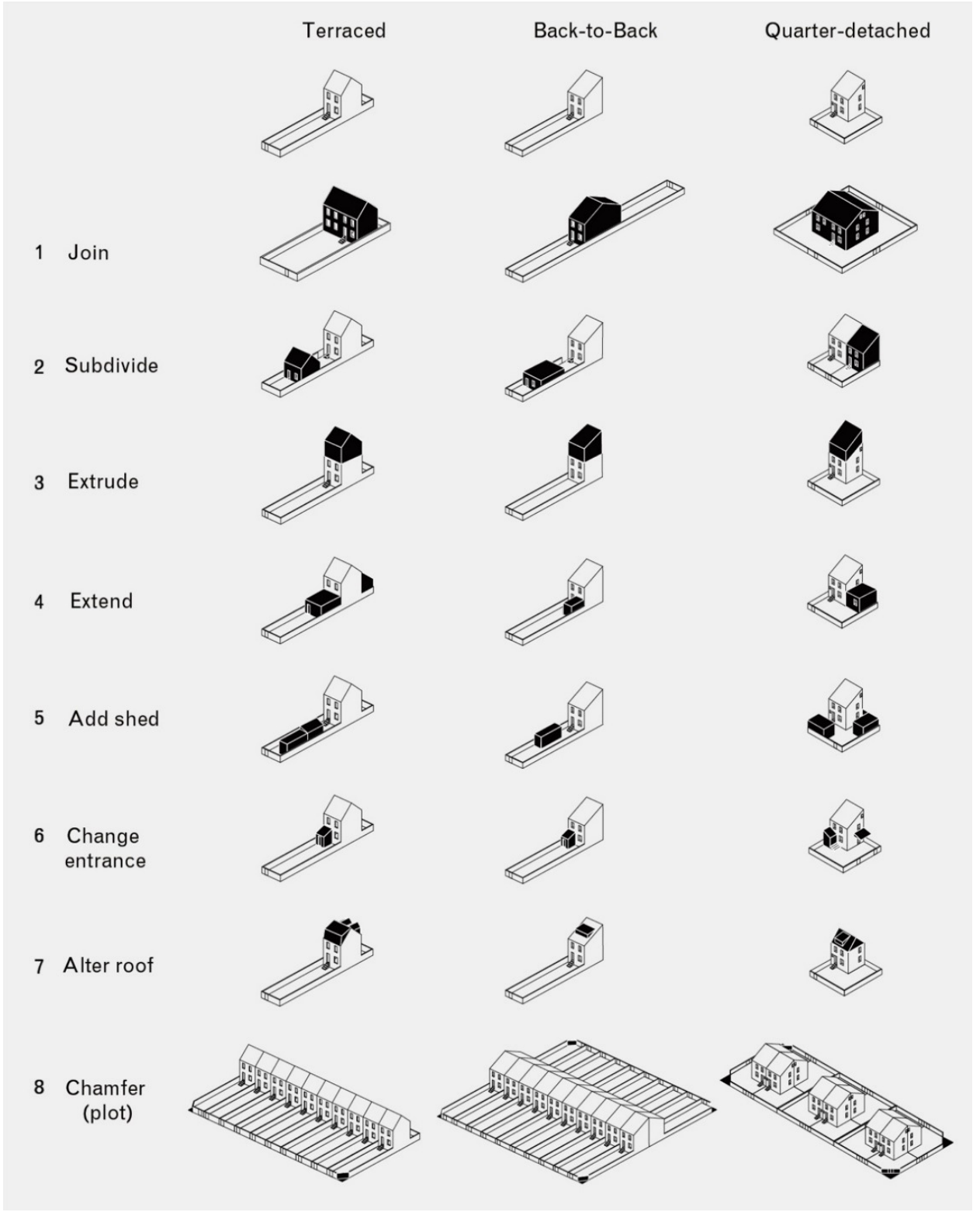

Figure 8. Types of exterior physical transformations found in the three main housing typologies of Cité Ouvrière in Mulhouse. Source: Kostourou (2020, p. 260).

Although the initial goal of the industrialists was to reform the social and moral state of the working-class through housing and ownership, it was their pioneering visions and actions that led them to co-fund the scheme, secure land, provide public infrastructure, introduce an innovative financial model, and initiate the new quarterdetached typology of carré mulhousien. With time, the socially enlightened capitalist approach gave way to a more liberal economic model, where design decisions were driven more by speculation than utility. This transition became evident both socially and spatially, particularly with the abandonment of communal facilities and the standardisation and shrinkage of houses. Regardless, both SOMCO and the municipality have been closely involved since the beginning in shaping the architectural and urban design of the scheme as well as its social and economic operation always in response to wider socioeconomic and political events.

Specifically, once the scheme was completed, the municipality-represented by the mayor, the delegated assistants, and the planning service-sought to regulate the establishment of non-domestic uses in the area, the conservation of the architectural patrimony, and the mitigation of the effect of physical growth to prevent the total degradation of the built environment. With the approval or rejection of building permit applications and the implementation of infrastructural works, they controlled whether changes would take place, how many and what kind were possible, and when, where, and how these would materialise, affecting the overall degree of physical transformation and by extension the architectural image of the entire neighbourhood. To illustrate 
this, the majority of physical changes occurred during the 1920s-1930s and 1950s-1960s, after the introduction of sewer pipelines and cars, which led to the construction of entrance porches and the chamfering of plot corners respectively.

However, regulations have not always preceded the construction and application processes. Although SOMCO, SIM, and Müller had predicted that adaptations would take place, especially after the residents became owners, still, they could never anticipate that rapid rate of change. This is why in the archival documents there sometimes were building rules ensuring the preservation of the original character of the scheme and the reformist aspirations of the industrialists and, other times, laws were only formally enacted after the inhabitants filed requests or unauthorised constructions were reported. The research showed that from the 259 unsuccessful building applications in 520 examined properties, 126 complied with the negative decision and 133 went on to realise the development without approval, from which only 44 were legalised afterwards by paying fines. In most cases, completed constructions were never legalised.

Therefore, it seems that there was-and there still is-some "flexibility" and considerable room for interpretation of the legal framework by the executive authorities. Indeed, regulations have been customised or revised on a case-by-case basis. For example, in one case, the municipality agreed on the extension and changes of facade, roof, and entrance by amending one of the articles of the Plan d'Occupation des Sols (Land-Use/Zoning Plan [POS]) of 1986 after evaluating the existing conditions, the nature of the project, and the improvement this would bring in terms of visual cohesion in the area. On a different occasion, the authorities showed willingness to disregard the violation of the minimum permitted distance ( $3 \mathrm{~m}$ as indicated by the POS of 1977) of a prefabricated garage from the property limit as long as the neighbours would give their consent. More recently, in 2000 , the municipality allowed the height of a backto-back house to be extended beyond the authorised maximum to better match its adjacent, already extruded buildings, and a year before they allowed the construction of a roof terrace because the neighbour had one too, despite terraces being prohibited by the POS of 1995.

Essentially, the spatial agency of the municipality has been effected locally through the enactment of building and zoning regulations and their adaptation on an if-andwhen-needed basis to respond to the changing demands of the residents, the local cultural habits and styles, and the architectural image of the Cité. However, at the neighbourhood level, their agency has been effected through the way the Cité had been initially planned and the way subsequent expansions of the wider city network ended up encircling the area, making it centrally located within the city-close to the city centre and adjacent to well-served quarters (Kostourou \& Karimi, 2017). It was a combination of planning decisions, visions, and actions that gradually transformed a suburban and uniform settlement into a denser and morphologically more diverse city quarter.

\subsection{The Architect}

The third agent of change is the architect Emile Müller, whose design decisions had a major influence on the potential of houses to grow and change. By deciding on specific building types and plots, their sizes and shapes, and their configuration in relation to each other and the street, he imposed geometrical and formal constraints that allowed certain possibilities to occur while inhibiting others (Kostourou, 2021). For example, the narrow and deep plots of row houses encouraged frontal extensions and the squared plots of quarter-detached houses allowed for double adjacency, prioritising beside extensions, and enabled plot and house accessibility from multiple points (Figure 8).

Notably, the original small houses offered residents the possibility to extend them both vertically and horizontally. The front gardens initially allowed for the cultivation of vegetables and the generation of income for the household, but they also left considerable open space on the ground floor for annexes, workshops, and garages to emerge. In fact, the surplus open space embedded in the original design has been found to be a key enabler for physical change and growth and a precondition for a "slow and contained densification process" like the one that followed (Kostourou, 2021). Furthermore, the planned narrow passages-tertiary streets only 2,5 $\mathrm{m}$ wide particularly present in the second and third development phases-were another conscious urban decision to accommodate water pumps in case of repair, to uphold the hygienic principles of the scheme, and to provide lateral connections within the neighbourhood, while offering intimate spaces for the daily interaction of the inhabitants. Müller himself had noticed after the first cité how well frequented these passages were, so he increased their number in the subsequent phases (Jonas, 2003).

In short, both the conceived and the actual design of buildings and plots facilitated, and to a certain extent even encouraged, subsequent alterations and additions in the built form. Although Müller's agency was effected more than 120 years ago, its impact on building and urban change has been catalytic till the present day.

\subsection{The Inhabitants}

The last-and admittedly the hardest to predict-agent of change is the workers and, more generally, the inhabitants residing in the housing scheme from the beginning. The first residents who accessed ownership, but also all the owners and tenants who have succeeded them since then, have taken an interest in investing both material and immaterial resources in the area. Not only have they spent energy, time, and money on maintaining 
and adapting their houses, ensuring they remain relevant and viable for more than 160 years, but they have also participated in communal activities, organised community groups, and developed social networks for different ethnic minorities, boosting feelings of belonging and identity (Kostourou, 2019).

Specifically, the local economic activities have invited more socio-economic groups into the area, building relationships among existing residents and newcomers and empowering the community. Especially after SOMCO declined the co-management of the cooperative Société de Consommation des Cités Ouvrières by the workersmembers (Grad, 1879), workers, together with traders and artisans, set up their own independent businesses and, in less than 20 years, the neighbourhood already counted 58 shops and workshops-one per 113 residents (Jonas, 2003). Meanwhile, the central location of the neighbourhood and the wider development of the city gradually made Cité Ouvrière a major residential draw for immigrants who sought to settle down in the city. Since the beginning of the 20th century, foreign workers from Germany, Switzerland, Italy, Poland, Northwest Africa, Turkey, and Portugal have moved into the area to work in public construction sites, potash mines, and automobile factories (Jonas, 2003; Stoerkel \& Vitoux, 2018). Even today there are more than 140 nationalities living in Mulhouse and Cité Ouvrière is among the most ethnically diverse parts of it (Meichler et al., 1998). Thus, by acting as "a reference arrival point and arena for intercultural encounters, contacts, and associations" (Kostourou, 2019, p. 87), the neighbourhood has managed to diversify itself ethnically, socially, and culturally, which has unquestionably diversified the motivations and actions of individuals who operate at its most intimate scale.

So far, the agency of the inhabitants has mainly been affected by the socio-economic logic of their households including issues of kinship, widowhood, inheritance, family growth or shrinkage, migration, etc.; the integration of micro-businesses in the same premises; and the frequent changes in the land ownership, which, as previous studies have shown (Boudon, 1972; Whitehand \& Carr, 2001), exerts an instrumental influence on the change of urban form. Specifically, there is a handful of cases where residents bought two or more adjacent properties which they either combined to increase the surface area of their house or turned into a multi-apartment building to generate income. Sometimes the owners did not live in the house but had themselves moved to one of the nearby suburbs and rented out the house to tenants. Sometimes, the inhabitants operated as developers, by buying multiple properties, investing in construction and repair work, and then selling or renting parts of them for profit. I also observed that residents living in nearby houses were often relatives or friends.

Growing houses, like those in the Cité, are ideal for multigenerational households or extended families, and for the operation of microbusinesses. As mentioned above, throughout the years, residents have repeatedly accommodated non-residential uses in their houses, like workshops, bars, shops, and market gardens, or converted entire buildings into hostels and restaurants. The combination of living-working has demanded adaptations in the buildings and plots to provide the spatial and infrastructural conditions needed for the operation of the businesses. A few examples include the installation of special machinery in the interior, like meat processing devices and refrigerators; the erection of garages, sheds, or storages in the garden for drivers, bakers, locksmiths, and repairmen; the expansion of kitchen and washrooms for restaurants; and the modification of facades with glass openings, often accompanied by advertisement signs. Growing families have also demanded the expansion of space. For instance, one of the Portuguese families who bought a quarter-detached house in 1982 has already made significant extensions to accommodate their adult children and grandchildren under the same roof.

Finally, frequent ownership changes of houses have also contributed to the high number of physical changes observed in the area as a result of individual lifestyles, whereas the close proximity of houses has helped the diffusion and perpetuation of similar kinds of changes through time. This has been partly because building practices and knowledge about how to adapt and grow the same houses have been disseminated between neighbours or passed on from one generation to another, and because the knowledge of what is feasible or possible to change has been acquired through trial and error, and some well-tested and highly visible solutions have been replicated by those living nearby-the so-called "neighbour effect" (Whitehand \& Carr, 2001, p. 167).

Ultimately, the spatial agency of the inhabitants has largely determined the survival of Cité Ouvrière over time, ensuring buildings remain fit for their purpose and maintain their lifetime value, while people sustain their social networks and economic activities. Historically, the individuals and the community have contributed to the making of a "do-it-yourself" spatial culture, which, as Jonas (2003) observes, is a common practice among low-income and disadvantaged populations with scarce resources. Yet, it is exactly this spatial culture that adds to the distinctive industrial character and cultural heritage of the neighbourhood.

Part of this emergent spatial culture has been manifested in the way the inhabitants have managed throughout the years to grow into "active agents of change," getting involved in the present and future of their neighbourhood, despite being excluded from the design and construction of the original settlement. By active spatial agency, I do not mean that people built the extensions and additions themselves-although some did-but rather that the decisions they took in terms of ownership, use, and real-estate development were vital in shaping the urban and built form of the area. In other words: 
The physical changes were essentially social and spatial expressions of active citizenship and design. This enabled inhabitants to shift from being [according to the words of Turner (1979)] passive consumers of housing goods and services to "active participants" in the aging of their homes and neighbourhood. (Kostourou, 2019, p. 92)

\section{Conclusions}

In this article I have discussed the main spatial agents involved in the formation and transformation of Cité Ouvrière in Mulhouse from 1853 to the present. I can group them into three sectors and summarise their motivations as follows: (1) the public sector, including the national government or the local municipality; (2) the private sector consisting of the industrialists and the housing association of SOMCO; and (3) the citizen sector, including all the workers and residents who have lived in the settlement since the end of 19th century. Within the limited geography of the case study and the particular period of study, the public sector was shown to be mainly driven by social-at times financial-aspirations; the private sector seemingly performed a public service, yet it was motivated by personal profit; and the inhabitants kept mostly acting out of personal interest in the proliferation of both their physical and human capital.

My second observation refers to constraints impacting their ability to implement changes. In summary, agents were constrained: (1) socio-economically, by international events (economic recessions, world wars, the decline of textile industry), political agendas (social reform, immigration), and micro-finances (internal logic of households); (2) spatially, by the topography of the land, the natural or infrastructural boundaries, the geometry of the streets, the dimensions and shape of plots and buildings, and the configuration of buildings within plots; and (3) legally, due to building regulations and planning documents, such as zoning plans, acts, ordinances, and decrees that specified minimum and maximum standards for any construction or alteration of buildings and plots. The question then is: How can built environment professionals plan for these constraints as tools for urban changeability? While the implications of certain decisions - for example, on city development, regulations, non-domestic functions, building size, open spaces, and street layout-can be more easily foreseeable, others that depend on national, even international, socio-economic and political changes and technological advancements and affect, for instance, housing supply and demand, available funds, immigration, or building changes can be harder to factor into the process.

One of the lessons learned from the example of the Mulhousian Cité is that collaboration between spatial agents at different levels may help overcome certain constraints and allow for change to occur in the future. One example is the PPP, which is, nowadays, a common neoliberal model to develop public projects financed by private capital. The model is highly controversial because, whilst PPP covers costs where the state is unable to provide funds and secures returns on investment by the private funder, it removes the accountability of the welfare state to provide social services and projects, not to mention the increasing privatisation of public assets. However, what differed in Mulhouse were the social aspirations driving the financial involvement of parties, which nonetheless remained unchanged despite the partial realisation of projet idéal and the gradual shift to a more speculative approach to housing supply. At the same time, decision makers were part of, and therefore advocates for both the private and the public sector (industrialists dominating the municipal cabinet), which implies there was a monitored effort to defend the interests of both parties involved.

Another case of mutual monitoring and collaboration occurred between the private housing association of SOMCO, which dominated the conception and making of the scheme, and the inhabitants, who drove its transformation over time. This rotation of spatial agency allowed for the complete transformation of a low-rise uniform suburban settlement into a dense, socially diverse, and formally heterogeneous city quarter. The piecemeal process of individuation that followed the delivery of the project provides another empirical lesson on certain questions that arise in the design process such as top-down versus bottom-up planning and liberty or constraint in the occupants' spatial agency. In the case of Cité Ouvrière, physical changes achieved a synthesis of uniformity and individuality in the design given a plain, regular, and functional layout. Once the basic infrastructure was provided, people could easily appropriate and build on it. Housing growth and change affected the architecture of individual buildings and the urban image of the whole settlement, without ever degrading them. Thanks to the original design as well as a common, yet limited, set of rules, types of physical transformations and shared reasons for change, formal unity, and plurality - rather than uniformity-were attained, thus ensuring a degree of consistency behind the ostensibly morphological heterogeneity, which better reflects the social diversity in the area.

Finally, Table 1 summarises the means instrumentalised by the various actors involved in the process, calling for a reflection on the changing nature of the built environment as a result of the changing and dynamic spatial agency of those actors at different spatial scales. In general, it can be concluded that the public sector can exert more power at the level of the city and the neighbourhood by dealing with the financial and infrastructural aspects of the project as well as the strategic planning within and outside the borders of an urban housing scheme. The private and citizen sector on the other hand, who may act both formally and informally and range from housing associations to architects, planners, and the local community, can play different roles at the level of the neighbourhood, individual buildings, 
Table 1. Summary of means of change employed by different agents at different scales.

\begin{tabular}{|c|c|c|c|}
\hline & City & Neighbourhood & Buildings and Plots \\
\hline State & $\begin{array}{l}\text { Adopt welfare approach to } \\
\text { working-class housing; } \\
\text { Promote reformist agenda. }\end{array}$ & $\begin{array}{l}\text { Get involved in PPP subsidising } \\
\text { private initiative for low-cost } \\
\text { housing. }\end{array}$ & - \\
\hline Municipality & $\begin{array}{l}\text { Plan, expand, and maintain the } \\
\text { street network; } \\
\text { Enact urban and land policies; } \\
\text { Set out strategic priorities for } \\
\text { development within different } \\
\text { quarters. }\end{array}$ & $\begin{array}{l}\text { Get involved in PPP subsidising } \\
\text { private initiative for low-cost } \\
\text { housing; } \\
\text { Secure land for housing schemes; } \\
\text { Provide public infrastructure to } \\
\text { housing schemes; } \\
\text { Support private initiatives and } \\
\text { their socio-economic models; } \\
\text { Set up legal framework to control } \\
\text { future urban changes. }\end{array}$ & $\begin{array}{l}\text { Establish and implement building } \\
\text { regulations; } \\
\text { Revise these regulations over } \\
\text { time in response to } \\
\text { contemporary needs and living } \\
\text { habits of the local community. }\end{array}$ \\
\hline $\begin{array}{l}\text { Private } \\
\text { Housing } \\
\text { Association }\end{array}$ & $\begin{array}{l}\text { Promote an innovative social } \\
\text { model and welfare work policy; } \\
\text { Offer workers access to } \\
\text { low-cost housing and } \\
\text { employment; } \\
\text { Promote social reform ideals } \\
\text { through housing; } \\
\text { Set up welfare childcare, } \\
\text { financial and educational } \\
\text { facilities. }\end{array}$ & $\begin{array}{l}\text { Provide welfare and public } \\
\text { amenities in low-cost housing; } \\
\text { Provide new model for } \\
\text { ownership with favourable terms } \\
\text { for workers; } \\
\text { Dispose of privately owned land } \\
\text { for low-cost housing project; } \\
\text { Standardise design for uniformity } \\
\text { and mass production; } \\
\text { Encourage small independent } \\
\text { businesses; } \\
\text { Revise and adjust the social and } \\
\text { operational model and economic } \\
\text { policy; } \\
\text { Tolerate physical changes } \\
\text { instigated by residents. }\end{array}$ & $\begin{array}{l}\text { Shape built form based on } \\
\text { financial profit and social } \\
\text { reform values; } \\
\text { Evaluate results from different } \\
\text { stages of development and } \\
\text { adjust policies; } \\
\text { Run post-occupational surveys } \\
\text { for inhabitants and the built } \\
\text { environment. }\end{array}$ \\
\hline Architect & $\begin{array}{l}\text { Integrate generous spatial } \\
\text { qualities and advanced hygienic } \\
\text { measures into urban planning; } \\
\text { Propose new model for living. }\end{array}$ & $\begin{array}{l}\text { Determine urban form; } \\
\text { Integrate new types of public and } \\
\text { private open spaces into the } \\
\text { design; } \\
\text { Adjust design during the } \\
\text { construction to economic policies } \\
\text { not entirely to the detriment of } \\
\text { social ideals. }\end{array}$ & $\begin{array}{l}\text { Determine building and plot } \\
\text { typologies; } \\
\text { Provide surplus of open space for } \\
\text { future growth or generation } \\
\text { of income. }\end{array}$ \\
\hline Inhabitants & - & $\begin{array}{l}\text { Engage in common activities and } \\
\text { organise community groups; } \\
\text { Develop and sustain social } \\
\text { networks and economic } \\
\text { activities; } \\
\text { Instigate individual physical } \\
\text { changes with larger aggregate } \\
\text { effect; } \\
\text { Push for changes in the legal } \\
\text { framework enacted by } \\
\text { municipality. }\end{array}$ & $\begin{array}{l}\text { Set up businesses in their } \\
\text { properties; } \\
\text { Instigate physical changes, invest } \\
\text { in the amelioration of built } \\
\text { environment to remain fit for its } \\
\text { purpose, and maintain its } \\
\text { lifetime value. }\end{array}$ \\
\hline
\end{tabular}


and plots, instigating smaller- or larger-scale changes in the built environment as a result of deliberate collaborations, contestations, and negotiations. While architects, public authorities, and private entities may often lead and, thus, influence the conception and development of urban housing projects, the ultimate agents of change are the inhabitants, and as such the ones who should be in a permanent dialogue with the former. The changes arising from the latter are smaller, more individual, localised, anonymous, asynchronous, self-motivated-at times self-regulated-and piecemeal, and thus perhaps quicker-to-undertake but harder-tocoordinate. Yet it is the aggregate effect that emerges from their incremental actions, irrespective of any central coordination or collective awareness, that drastically contributes to the changing of the wider urban built environment. It is this aggregate effect that architects, planners, and authorities of contemporary cities will need to anticipate and plan for when developing residential and urban areas to ensure they change and age well in time.

\section{Acknowledgments}

This study is part of doctoral research undertaken at the UCL Bartlett School of Architecture between 2014 and 2019 with the support of the Engineering and Physical Sciences Research Council (515565). The author would like to thank the staff of the municipal archives of Mulhouse for their assistance during fieldwork as well as the reviewers and editors for their feedback and support.

\section{Conflict of Interests}

The author declares no conflict of interests.

\section{References}

Awan, N., Schneider, T., \& Till, J. (2013). Spatial agency: Other ways of doing architecture. Routledge.

Boissière, E. (1876). Vingt ans à Mulhouse, 1855-1875 [Twenty years in Mulhouse, 1855-1875]. Emile Protat.

Boudon, P. (1972). Lived-in architecture: Le Corbusier's Pessac revisited. MIT Press.

Brand, S. (1994). How buildings learn: What happens after they're built. Viking Press.

Bullock, N., \& Read, J. (1985). The movement for housing reform in Germany and France 1840-1914. Cambridge University Press.

Canopé Académie de Strasbourg. (n.d.). Trois types de maisons [Three types of houses]. http://www.crdpstrasbourg.fr/data/albums/cite_ouvriere/index.php? img=20\&parent $=1$

Clement, W. (2018). The "unrealizable chimera": Workers' housing in nineteenth-century Mulhouse. French History, 32(1), 66-85. https://doi.org/10.1093/fh/ crx096

Conzen, M. R. G. (1988). Morphogenesis, morphological regions and secular human agency in the historic townscape, as exemplified by Ludlow. In D. Denecke \& G. Shaw (Eds.), Urban historical geography: Recent progress in Britain and Germany (pp. 253-272). Cambridge University Press.

de Gier, E. (2014, November 14-15). Avant-garde welfare capitalism: Corporate welfare work and enlightened capitalism in Great Britain, the US, Germany and France (1880-1930) [Paper presentation]. International Conference on Social Boundaries of Work: Changes in the Sphere of Work in the 21st Century, Wrocław, Poland.

de Lacroix, M. C. (1901). De 1887 à 1897. Note du Comité d'utilité publique pour faire suite au rapport du Dr. Penot sur les cités ouvrières [From 1887 to 1897. Note from the Public Utility Committee following up on Dr. Penot's report on the workers' housing estates]. In Bulletin de la Société Industrielle de Mulhouse (pp. 447-452). Société Industrielle Mulhouse Haut-Rhin.

Ducpétiaux, E. (1846). Projet d'association financière pour l'amélioration des habitations et l'assainissement des quartiers habités par la classe ouvrière [Financial association project for the improvement of housing and the sanitation of neighbourhoods inhabited by the working class]. Meline, Cans et Compagnie.

Ermenc, J. J. (1957). Avant-garde capitalism in France. The French Review, 31(2), 129-135. https://doi.org/ $10.2307 / 383540$

Garner, J. S. (1992). The company town: Architecture and society in the early industrial age. Oxford University Press.

Giddens, A. (1984). The constitution of society: Outine of the theory of structuration. University of California Press.

Grad, C. (1879). Études statistiques sur l'Industrie de I'Alsace [Statistical studies on Alsace's industry] (Vol. 2). Eugène Barth, Noiriel, \& Guillaumin et Cie.

Guerrand, R.-H. (1967). Les origines du logement social en France [The origins of social housing in France]. Éditions Ouvrières.

Hillier, B. (1989). The architecture of the urban object. Ekistics, 56(334/335), 5-21.

Honhart, M. (1990). Company housing as urban planning in Germany, 1870-1940. Central European History, 23(1), 3-21.

Jonas, S. (1994). Le Mulhouse industriel: Un siècle d' histoire urbaine (1740-1848) [The industrial Mulhouse: A century of urban history (1740-1848)] (Vol. 1). L'Harmattan.

Jonas, S. (2003). Mulhouse et ses cités ouvrières: Perspective historique, 1840-1918. Quatre-vingts ans d'histoire urbaine et sociale du logement ouvrier d'origine industrielle [Mulhouse and its workingclass settlements: Historical perspective, 1840-1918. Eighty years of urban and social history of industrial workers' housing]. Oberlin.

Kostof, S. (1992). The city assembled: The elements of 
urban form through history. Thames \& Hudson.

Kostourou, F. (2019). Mass factory housing: Design and social reform. Design Issues, 35(4), 79-92. https:// doi.org/10.1162/desi_a_00567

Kostourou, F. (2020). Adaptability of the urban form: Mapping changes over time and across scales in the Cité Ouvrière of Mulhouse [Doctoral dissertation, University College London]. UCL Discovery. https:// discovery.ucl.ac.uk/id/eprint/10096594

Kostourou, F. (2021). Housing growth: Impacts on density, space consumption and urban morphology. Buildings and Cities, 2(1), 55-78. https://doi.org/ 10.5334/bc.75

Kostourou, F., \& Karimi, K. (2017). The integration of new social housing in existing urban schemes: The case of Cité Manifeste in Mulhouse, France. Urban Morphology, 21(1), 41-60.

Kropf, K. S. (2001). Conceptions of change in the built environment. Urban Morphology, 5(1), 29-42.

Latour, B. (2005). Reassembling the social: An introduction to actor-network theory. Oxford University Press.

Meichler, F., Birot, S., \& Freyburger, P. (1998). Mulhouse d'ailleurs: Enquête sur l'immigration dans la ville [Mulhouse elsewhere: Survey of immigration in the city]. Éditions du Rhin.

Monange, J. (2001). De la valeur des choses dans le temps [Of the value of things over time]. HistoireGénéalogie: La Vie \& la Mémoire des Hommes. http://www.histoire-genealogie.com/De-la-valeurdes-choses-dans-le-temps?lang $=\mathrm{fr}$

Müller, E., \& Cacheux, E. (1889a). Les habitations ouvrières en tous pays [Workers' dwellings in all countries]. Baudry \& Cie.

Müller, E., \& Cacheux, E. (1889b). Les habitations ouvrières en tous pays (2e édition)-Atlas de 78 planches [Workers' dwellings in all countries (2nd edition)-Atlas of 78 boards]. Baudry \& Cie.

Penot, A. (1867). Les cités ouvrières de Mulhouse et du département du Haut-Rhin [The working-class settlements of Mulhouse and the Haut-Rhin department]. L. L. Bader.

Roberts, H. (1867). The dwellings of the labouring classes: Their arrangement and construction with the essentials of a healthy dwelling. Society for Improving the Condition of the Labouring Classes.

Scheurer, M.-P., \& Lehni, R. (1990). Mulhouse, Haut-Rhin: Inventaire général des monuments et des richesses artistiques de la France [Mulhouse, Haut-Rhin: General inventory of monuments and artistic riches of France]. Commission Régionale Alsace.
Schmitt, J.-M., \& Jenkins, D. (1982). The origins of the textile industry in Alsace: The beginnings of the manufacture of printed cloth at Wesserling (1762-1802). Textile History, 13(1), 99-109. https://doi.org/ 10.1179/tex.1982.13.1.99

Schneider, T., \& Till, J. (n.d.). About. Spatial Agency. https://www.spatialagency.net/about

Shapiro, A.-L. (1985). Housing the poor of Paris, 1850-1902. University of Wisconsin Press.

Simon, J. (1861). L'ouvrière [The worker]. Hachette.

Smets, M. (1977). L'avènement de la cité-jardin en Belgique: Histoire de l'habitat social en Belgique de 1830 à 1930 [The advent of the garden-city in Belgium: History of social housing in Belgium from 1830 to 1930]. Mardaga.

Steadman, P. (2014). Building types and built forms. Troubador.

Stoerkel, J.-M., \& Vitoux, M.-C. (2018, December 23). Mulhouse est l'archétype de la ville fabriquée par les flux migratoires [Mulhouse is the archetype of the city made by migratory flows]. L'Alterpresse68. https://www.alterpresse68.info/2018/12/23/marieclaire-vitoux-mulhouse-est-larchetype-de-la-villefabriquee-par-les-flux-migratoires

Tarn, J. N. (1973). Five percent philanthropy: An account of housing in urban areas between 1840 and 1914. Cambridge University Press.

Turner, J. F. C. (1979). Mass housing and user participation. Built Environment, 5(2), 91-98. http://www. jstor.org/stable/23285925

Véron, E. (1866). Les institutions ouvrières de Mulhouse et des environs [Labour institutions in Mulhouse and surrounding areas]. Hachette.

Viaene, P. (1994). Le concept de "cité ouvrière" du chirurgien Adolphe Burggraeve (1806-1902) dans le cadre de l'amélioration des conditions de logement des travailleurs à Gand (Belgique) au XIX siècle [The concept of the working-class settlement by the surgeon Adolphe Burggraeve (1806-1902) as part of the improvement of the housing conditions of workers in Ghent (Belgium) in the 19th century]. L'Archéologie Industrielle en France: Patrimoine, Technique, Mémoire, 2, 15-36.

Whitehand, J. W. R. (1992). The making of the urban landscape. Wiley.

Whitehand, J. W. R., \& Carr, C. M. H. (2001). Twentiethcentury suburbs: A morphological approach. Routledge.

Yaneva, A. (2012). Mapping controversies in architecture. Ashgate.

\section{About the Author}

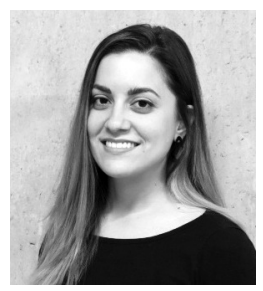

Fani Kostourou is an associate at Theatrum Mundi, leading on research, design, and creative development, and teaches at Cardiff University, UCA Canterbury School of Architecture, and UAL Central Saint Martins. She is an architect and urbanist, holding a PhD from UCL Bartlett on diachronic processes of growth and change in the urban form. Fani conducts research, engages in curatorial and editorial work, and publishes internationally on design, computation, critical and interdisciplinary spatial theories, housing, and urban cultures. 